\title{
Effect of weather parameters on seasonal incidence of pod borer complex in pigeonpea
}

\author{
B. L. JAT ${ }^{1}$, K. K. DAHIYA ${ }^{1}$, ROSHAN LAL ${ }^{1}$ and RAM NIWAS ${ }^{2}$ \\ ${ }^{1}$ Department of Entomology, ${ }^{2}$ Department of Agrometeorology, \\ CCS Haryana Agricultural University, Hisar-125 004, Haryana \\ *Email:bljat.hau@gmail.com
}

\begin{abstract}
Field experiments were conducted at CCS Haryana Agricultural University, Hisar during kharif season of 2013 and 2014 to determine the effect of weather parameters on the incidence of pod borer complex on early maturing pigeonpea varieties. The study revealed that the infestation of Helicoverpa armigera and Maruca vitrata started with the onset of bud initiation and reached its peak at flowering stage. The maximum $H$. armigera larval population (1.83 larvae plant $\left.{ }^{-1}\right)$ was recorded in $1^{\text {st }}$ week of July sown crop, whereas, the maximum incidence of $M$. vitrata $\left(21.17\right.$ webs plant $\left.^{-1}\right)$ was recorded in $2^{\text {nd }}$ week of July sown crop. The larval population of $H$. armigera was significantly and positively correlated with the maximum temperature, followed by minimum temperature. Incidence of $M$. vitrata was negatively correlated with evening relative humidity and wind speed which was significant at $p \leq 0.05$ level of significance.
\end{abstract}

Keywords: Weather parameters, seasonal incidence, Helicoverpa armigera, Maruca vitrata

Pigeonpea [Cajanuscajan(L.) Millspaugh]is one of the major pulse crops grown between $30^{\circ} \mathrm{N}$ and $30^{\circ} \mathrm{S}$ in the semi-arid tropics and is the second most important pulse crop of India, after chickpea. In Haryana, pigeonpea is grown under 15.1 thousand hectares with an annual production of 16.4 thousand tones leading to a productivity of $1086 \mathrm{~kg} \mathrm{ha}^{-1}$.

A large number of insect pests (more than 300 species) has been reported which attack pigeonpea crop. The most important pests those attack at flowering and podding stage of the crop are pigeonpea pod borer, Helicoverpa armigera and spotted pod borer, Maruca vitrata (Fabricius). Damage to pods due to the borer complex was reported to be 20 to 72 per cent. In long duration varieties $H$. armigera infestation of 15.6 per cent was recorded, whereas, $M$. vitrata infestation was upto 16.4 per cent in short duration varieties. In Haryana, the pod damage by pod borers was as high as 10 to 35 per cent (Chauhan, 1992).

According to Akhauri (1992), the population buildup of pod borer, $M$. vitrata varied remarkably in different parts of the country probably due to differences in agro climatic conditions and crop types. The larval population of $M$. vitrata was significantly influenced by average temperature and relative humidity at Hisar (Naresh and Singh, 1984).

\section{MATERIALS AND METHODS}

To study the incidence of pod borer complex and effect of abiotic factors on their population fluctuation, an experiment was conducted at Pulses Farm, Department of Genetics and Plant Breeding, CCS Haryana Agricultural University, Hisar, Haryana during the kharif seasons of 2013 and 2014 with six pigeonpea varieties (Manak, Paras, Pusa-992, AL-201, PAU-881 and H03-41) raised on four dates $\left(D_{1}-3^{\text {rd }}\right.$ week of June, $D_{2}-T 1^{\text {st }}$ week of July, $D_{3}-T 2^{\text {nd }}$ week of July and $\mathrm{D}_{4}-\mathrm{T} 3^{\text {rd }}$ week of July), in plot size of 4 rows of $4 \mathrm{~m}$ length with spacing of $45 \mathrm{~cm} \times 15 \mathrm{~cm}$ keeping three replications in randomized complete block design. All the recommended agronomic practices were followed for raising the crop. The plots were kept without insecticidal umbrella to allow pod borer complex to multiply throughout the cropping season. The visual observations on the incidence of $H$. armigera and $M$. vitrata were taken when the pest appeared in the field till crop maturity. The larvae of the pod borer, H. armigera and webs of spotted pod borer, M. vitrata were recorded at fortnight intervals from 5 tagged plants from each plot per replication. The seasonal population of pod borer complex was correlated with the meteorological weather parameters viz., maximum temperature (Tmax), minimum temperature (Tmin), rainfall, morning relative humidity $\left(\mathrm{RH}_{\mathrm{M}}\right)$, evening relative humidity $\left(\mathrm{RH}_{\mathrm{E}}\right)$, morning vapor pressure $\left(\mathrm{VP}_{\mathrm{M}}\right)$, evening vapor pressure $\left(\mathrm{VP}_{\mathrm{E}}\right)$, bright sunshine hours (BSS), wind speed (WS) and evapotranspiration (EP) using standard statistical procedure as suggested by Steel and Torrie (1980). 

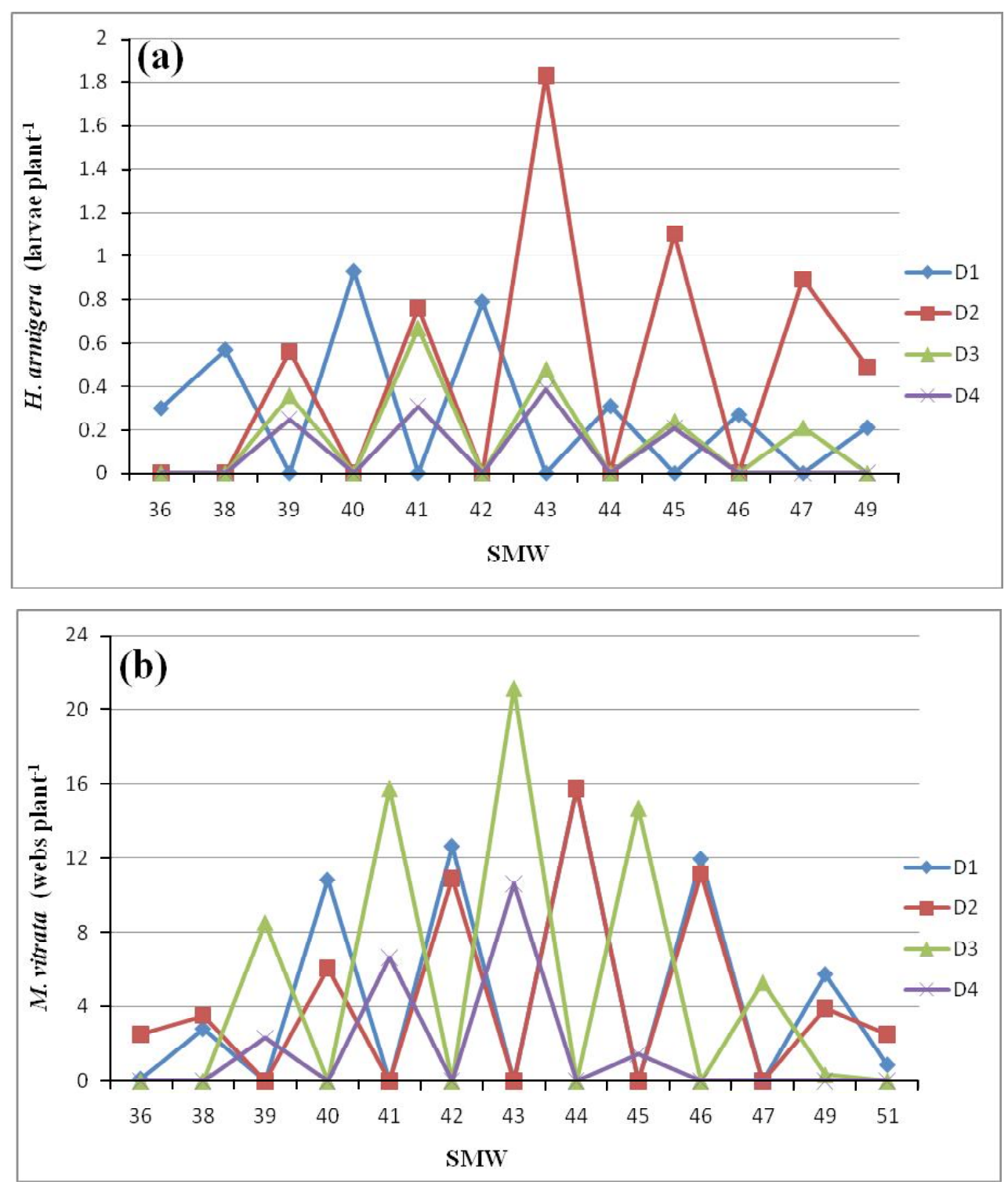

Fig. 1 : Incidence of pigeonpea pod borer (a) H. armigeraand (b)M. vitrata in different dates of sowing $\mathrm{D}_{1}\left(3^{\text {rd }}\right.$ week of June $) ; \mathrm{D}_{2}\left(1^{\text {st }}\right.$ week of July $) ; \mathrm{D}_{3}\left(2^{\text {nd }}\right.$ week of July $) ; \mathrm{D}_{4}\left(3^{\text {rd }}\right.$ week of July $)$ SMW $=$ Standard Meteorological Week

\section{RESULTS AND DISCUSSION}

\section{Population dynamics}

H. armigera: The data on incidence of pod borer complex in pigeonpea was pooled for the years 2013 and 2014 and are presented in (Fig. 1a). The results revealed that the larval population of $H$. armigera in $\mathrm{D}_{1}\left(3^{\text {rd }}\right.$ week of June $)$ sown crop was started in $36^{\text {th }}$ SMW ( $\left(1^{\text {st }}\right.$ week of September $)(0.30$ larvae plant $\left.^{-1}\right)$ and gradually increased (0.93 larvae plant $\left.{ }^{-1}\right)$ up to $40^{\text {th }} \mathrm{SMW}$. Thereafter the larval population decreased.The late sown crop experience less incidence of $H$. armigera. Gowda et al. (2012) have reported that pigeonpea crop sown in July II fortnight resulted in higher incidence of pod borer as compared to early sowing in June I fortnight. Kabaria et al.(1993) also suggested that early sowing of the pigeonpea crop during the first week of June avoid pod borer damage.

M.vitrata:The data on incidence of $M$. vitrata (Fig. 1 b) revealed that the $M$. vitrata incidence in $\mathrm{D}_{1}\left(3^{\text {rd }}\right.$ week of June) sown crop commenced in $36^{\text {th }} \mathrm{SMW}$ ( $1^{\text {st }}$ week of September) and reached its peak of 15.74 webs plant $^{-1}$ in $44^{\text {th }}$ SMW and the incidence declined thereafter. $\operatorname{In~}_{2}\left(1^{\text {st }}\right.$ week of July), $\mathrm{D}_{3}\left(2^{\text {nd }}\right.$ week of July) and $\mathrm{D}_{4}\left(3^{\text {rd }}\right.$ week of July) sown crops the incidence of $M$. vitrata commenced in $39^{\text {th }}$ SMW ( $4^{\text {th }}$ week of September) with 2.52, 8.54 and 2.31 webs plant ${ }^{-1}$, respectively with the maximum pest incidence 
Table 1: Correlation coefficient of H. armigera and M. vitrata population with abiotic factors in different sowing dates (Pool of seasons, $2013 \& 2014$ )

\begin{tabular}{|c|c|c|c|c|c|c|c|c|}
\hline \multirow{2}{*}{$\begin{array}{l}\text { Weather } \\
\text { Parameters }\end{array}$} & \multicolumn{4}{|c|}{ H. armigera } & \multicolumn{4}{|c|}{ M. vitrata } \\
\hline & D1 & D2 & D3 & D4 & D1 & $\mathrm{D} 2$ & D3 & D4 \\
\hline Tmax & $0.626 * *$ & 0.162 & $0.743 *$ & -0.248 & 0.146 & -0.200 & $0.704^{*}$ & -0.340 \\
\hline Tmin & $0.537^{*}$ & 0.160 & 0.574 & -0.067 & -0.175 & $-0.653 *$ & 0.476 & -0.179 \\
\hline $\mathrm{VP}_{\mathrm{M}}$ & $0.518^{*}$ & 0.087 & 0.500 & 0.019 & -0.255 & $-0.688^{*}$ & 0.414 & -0.104 \\
\hline $\mathrm{VP}_{\mathrm{E}}$ & 0.384 & 0.042 & 0.374 & 0.111 & -0.405 & $-0.762 * *$ & 0.312 & -0.017 \\
\hline $\mathrm{RH}_{\mathrm{M}}$ & -0.345 & -0.038 & -0.245 & 0.330 & -0.139 & 0.274 & -0.399 & 0.422 \\
\hline $\mathrm{RH}_{-}$ & 0.118 & -0.092 & 0.080 & $0.912 * *$ & $-0.671 * *$ & $-0.586^{*}$ & -0.564 & $0.906^{*}$ \\
\hline WS & 0.109 & -0.189 & 0.389 & -0.087 & $-0.533^{*}$ & $-0.829 * *$ & 0.149 & -0.160 \\
\hline BSS & 0.476 & -0.228 & 0.090 & -0.278 & 0.163 & 0.091 & 0.496 & -0.384 \\
\hline EP & 0.420 & -0.136 & 0.414 & -0.196 & -0.164 & -0.374 & 0.392 & -0.289 \\
\hline Rainfall & -0.059 & -0.377 & $0.829 * *$ & 0.186 & $-0.552 *$ & -0.454 & 0.282 & 0.219 \\
\hline
\end{tabular}

$\mathrm{D}_{1}\left(3^{\text {rd }}\right.$ week of June $) ; \mathrm{D}_{2}\left(1^{\text {st }}\right.$ week of July $) ; \mathrm{D}_{3}\left(2^{\text {nd }}\right.$ week of July $) ; \mathrm{D}_{4}\left(3^{\text {rd }}\right.$ week of July $)$

of 15.72, 21.17 and 10.60 webs plant $^{-1}$. The incidence of $M$. vitrata was less under late sown condition, similar to that observed in case of H. armigera (Fig. 1). Sujithra and Chander (2014) reported that the incidence of $M$. vitrata infestation was maximum in late sown pigeonpea crop.

\section{Correlation with weather parameters}

H. armigera: The correlations between weather parameters and larval population of $H$. armigera under different sowing dates (Table 1), revealed that the significant and positive association with $\operatorname{Tmax}\left(\mathrm{r}=0.626^{* *}\right), \operatorname{Tmin}\left(\mathrm{r}=0.537^{*}\right)$ and $\operatorname{VPm}\left(\mathrm{r}=0.518^{*}\right)$ under early sown crops $\left(\mathrm{D}_{1}\right)$. None of the other weather parameters had significant association with the larval population under $\mathrm{D}_{1}$ and $\mathrm{D}_{2}$. Under $\mathrm{D}_{3}$ sown crop only Tmax $(r=0.743 *)$ and rainfall $\left(r=0.829^{* *}\right)$ had significant correlations. In late sown crop $\left(\mathrm{D}_{4}\right)$ significant and positive correlation $(\mathrm{r}=0.912 * *)$ was observed with evening relative humidity $\left(\mathrm{VP}_{\mathrm{E}}\right)($ Table 1$)$.

Borah and Dutta (2004) had also reported a positive and significant correlation of $H$. armigera larvae with the maximum and minimum temperatures.

M. vitrata: The correlation between weather parameters and incidence of $M$. vitrata revealed that in early sown $\operatorname{crop}\left(\mathrm{D}_{1}\right)$ $\mathrm{RH}_{\mathrm{E}}\left(\mathrm{r}=-0.671^{*}\right)$, rainfall $\left(\mathrm{r}=-0.552^{*}\right)$ and $\mathrm{WS}\left(\mathrm{r}=-0.533^{*}\right)$ showed significant and negative association with the $M$. vitrata web. Under second date of sowing most of the weather parameters had negative correlation, however, the significant were with wind speed $\left(\mathrm{r}=-0.829^{* *}\right)$, followed by $\mathrm{VP}_{\mathrm{E}}(\mathrm{r}=-0.762 * *), \operatorname{Tmin}\left(\mathrm{r}=-0.653^{*}\right)$ and rainfall $(\mathrm{r}=-$ $\left.0.583^{*}\right)$. Pest incidence in $3^{\text {rd }}$ and $4^{\text {th }}$ dates of sowing was significantly and directly associated with maximum temperature and relative humidity. M. vitrata web incidence showed differential response to weather parameters under different sowing environments.

Sahoo and Behera (2001) had reported a positive correlation between populations of $M$. vitrata and the minimum and maximum temperatures and relative humidity, whereas, population of pod borers was adversely affected by the intensity of rain fall. Kalola et al. (2017) also reported a negative association between pink bollworm catches in cotton growing area and minimum temperature in Gujarat.

\section{REFERENCES}

Akhauri, R.K. (1992). Management of pod borer complex in pigeonpea, Cajanus cajan (L) Millsp through varietal reaction, intercropping and insecticidal application. Ph.D thesis submitted to R.A.U., Bihar,Pusa.

Borah, S.R. and Dutta, S.K. (2004). Seasonal incidence of Helicoverpa armigera Hubner larvae on pigeonpea. Bioved, 15(1/2): 127130.

Chauhan, R. (1992). Present status of Heliothis armigera in pulses and strategies for its management in Haryana (Eds. Sachan J.N.) Helicoverpa Management: Current status and Future strategies, Proc. First Nat. Workshop, Directorate of Pulses Research, Kanpur, India. 49-54 pp

Gowda, P.T., Halikatti, S.I., Hiremath, S.M., Nandihalli, B.S., Venkatesh,H. andAravindkumar, B.N.(2012). Effect of 
planting dates and cropping systems on the incidence pigeonpea podborer (Helicoverpa armigera) in northern transition zone of Karnataka. J. Exp.Zool. India, 15 (2): 661-665.

Kabaria, B.B., Goyal, S.N., Jose, V.T. and Shah, A.H. (1993). Effect of sowing time in relation to different varieties on major insect pests and grain yield of pigeonpea in Gujarat State. Indian J. Ent., 55: 52-57.

Kalola,A.D.,Parmar D.J., Motka, G.N.,Vaishnav,P.R., Bharpoda, T.M. and Borad,P.K.(2017). Weatherbased relationships of adult moth catches of pink bollworm( $P$.gossypiella) and leaf eating caterpillar (S. litura) in cotton growing area of Anand, Gujarat. J. Agrometeorol.,19(1):75-77.

Naresh, J.S. and Singh, J. (1984). Population dynamics and damage caused by insect pests in flowering pigeonpea (Cajanus cajan (L) Millsp, Indian J.Ent.,46 (4): 412420.

Sahoo, B.K. and Behera, U.K. (2001). Influence of abiotic factors on the incidence of pigeonpea pod borers in coastal belt of Orissa. Environ. \& Ecol., 19(4): 882884.

Sujithra, M. and Chander, S. (2014). Seasonal incidence and damage of major insect pests of pigeonpea, Cajanus cajan (L.). Indian J. Ent., 76: 202-206. 